\title{
HELLP syndrome, a difficult diagnosis: a case report
}

\section{Shweta Pradhan*, Somen Bhattacharjee}

Department of Obstetrics and Gynecology, MGM Medical College and MY Hospital, Indore, Madhya Pradesh, India

Received: 16 February 2019

Accepted: 07 March 2019

\section{*Correspondence:}

Dr. Shweta Pradhan,

E-mail: shwetapradhan22@gmail.com

Copyright: (c) the author(s), publisher and licensee Medip Academy. This is an open-access article distributed under the terms of the Creative Commons Attribution Non-Commercial License, which permits unrestricted non-commercial use, distribution, and reproduction in any medium, provided the original work is properly cited.

\begin{abstract}
HELLP is an acronym that refers to a syndrome characterized by Haemolysis with a microangiopathic blood smear, Elevated Liver enzymes, and a Low Platelet count. Recent studies suggested that some women will develop HELLP without the manifestations of classical symptoms. Authors present the case of a 22-year-old normotensive primigravida who went into severe thrombocytopenia and haemolysis leading to DIC, finally the diagnosis of normotensive HELLP syndrome was made. Present case report attempts to illustrate the diagnostic dilemma that a clinician faces in diagnosing an atypical presentation of HELLP syndrome. Management of jaundice during pregnancy especially in third trimester remains a dilemma for the obstetrician because of its varied aetiology, unpredictable prognosis and guarded perinatal outcome. Authors therefore recommend a rational stepwise approach toward the diagnosis of HELLP syndrome and its atypical presentation.
\end{abstract}

Keywords: ALFP, HELLP, Normotensive HELLP

\section{INTRODUCTION}

HELLP is an acronym that refers to a syndrome characterized by Haemolysis with a microangiopathic blood smear, Elevated Liver enzymes, and a Low Platelet count. ${ }^{1}$ It probably represents a severe form of preeclampsia, but the relationship between the two disorders remains controversial. HELLP develops in approximately $0.1-0.8 \%$ of pregnancies overall and as many as $15-20 \%$ of patients with HELLP syndrome do not have antecedent hypertension or proteinuria, leading some authorities to believe that HELLP is a separate disorder from preeclampsia.

Recent studies suggested that some women will develop HELLP without the manifestations of classical symptoms. $^{2}$ Authors present the case of a 22-year-old normotensive primigravida who went into severe thrombocytopenia and haemolysis leading to DIC finally the diagnosis of normotensive HELLP syndrome was made.

\section{CASE REPORT}

A 22 years old primigravida with 39 weeks period of gestation was referred from a peripheral hospital to our tertiary care center with complaints of epigastric pain, yellow discoloration of urine and eyes, malaise, anorexia and vomiting since 2-3 days.

A written consent was obtained by and explained to patient and relatives at every step of management and also for using the data for academic purposes in future.

She had no complaints of leaking or bleeding per vaginum or decreased fetal movement. No complains of headache , blurring of vision or convulsions. There was no significant past history. Patient had one ANC visit at 11 weeks of pregnancy. On examination she was conscious, oriented to time, place and person, cooperative and responding appropriately to verbal commands. The patient was well hydrated and afebrile. Her blood pressure was $120 / 84 \mathrm{~mm} \mathrm{Hg}$ and pulse rate was 84 per 
min. She had icterus and mild pedal edema. Her cardiovascular and respiratory systems were within normal limits on examination.

Abdominal examination revealed relaxed uterus of 32 weeks size, with fetus in cephalic presentation and normal fetal heart rate. On per vaginal examination, cervical OS was $2 \mathrm{~cm}$ dilated, $10-20 \%$ effaced ,membrane absent and head just at brim. Pelvis seemed adequate. Patient was admitted to ICU, urgent laboratory investigations were sent. Antimicrobials were started. Medical management of jaundice was started.
A differential diagnosis of acute viral hepatitis, HELLP syndrome or Acute fatty liver of pregnancy(AFLP) was made. A presumptive diagnosis of HELLP was entertained as her viral serology turned out to be negative for hepatitis A, B, and E. Her bilirubin levels and liver enymes levels (Table 1), made it less likely to be ALFP as it did not satisfy the clinical criteria (swansea criteria) for ALFP. A decision was taken to induce labour after correction of the coagulation profile by transfusing 2 units of fresh frozen plasma (FFP). The patient was induced with dinoprostone gel followed by oxytocin augmentation.

Table 1: Biochemical parameters at different intervals of admission.

\begin{tabular}{|c|c|c|c|c|c|c|c|c|c|}
\hline Investigation & $\begin{array}{l}\text { Blood } \\
\text { sugar } \\
(\mathrm{mg} / \mathrm{dl})\end{array}$ & $\begin{array}{l}\mathrm{Hb} \\
(\%)\end{array}$ & $\begin{array}{l}\text { TLC } \\
\text { (per } \\
\text { microliter) }\end{array}$ & $\begin{array}{l}\text { PLT } \\
\text { (per } \\
\text { microliter) }\end{array}$ & $\begin{array}{l}\text { SGOT } \\
\text { (per } \\
\text { litre) }\end{array}$ & $\begin{array}{l}\text { SGPT } \\
\text { (per } \\
\text { litre) }\end{array}$ & $\begin{array}{l}\text { Total } \\
\text { bilirubin } \\
\text { (mg/dl) }\end{array}$ & $\begin{array}{l}\text { Unconjugated } \\
\text { bilirubin } \\
\text { (mg/dl) }\end{array}$ & $\operatorname{In} R$ \\
\hline 1 at admission & 60 & 10.2 & 17000 & 73000 & 56.3 & 60.9 & 3 & 1.7 & 1.8 \\
\hline $\begin{array}{l}12 \text { hours after } \\
\text { admission }\end{array}$ & 78 & 8.4 & 21000 & 60000 & 98 & 71 & 6 & 4 & 2 \\
\hline $\begin{array}{l}24 \text { hours after } \\
\text { admission }\end{array}$ & 84 & 7.1 & 32000 & 44000 & 205 & 110 & 6.4 & 4 & 3.01 \\
\hline
\end{tabular}

Once the diagnosis of HELLP is made, the definitive management is early delivery of the fetus. ${ }^{3}$ However, the crucial decision of timing of delivery is made even more difficult by the presence of derangement in the coagulation profile. It has been seen that such patients respond well to induction of labour and it is not essential to perform a caesarean section. ${ }^{4}$ In fact, at the present center authors try and avoid surgical intervention in the presence of coagulation failure.

In view of rising liver enzymes, falling $\mathrm{Hb}$ and platelet counts suspicion of normotensive HELLP became stronger. LDH(Lactate Dehydrogenase) was requested and came out elevated $864 \mathrm{IU} / \mathrm{ml}$. It was more than 24 hours from admission, and to make the condition all the more complicated, inspite of oxytocin augmentation patient failed to progress during second stage of labour, with fetal head still at 0 station. Patient was planned for Caesearn section with 2 units FFP, 2 units PRP (platelet rich plasma) and 2 units whole blood in hand. A $2.3 \mathrm{~kg}$ female baby was delivered, head was deflexed and multiple congenital deformities were noted as short neck with abnormal neck muscles, poorly developed maxilla and nasal bone defects explaining the protracted course of labor. Intra operative patient maintained her vitals well .Patient was closed with abdominal drain in situ . A dose of 800 microgram misoprost was given immediate postoperative, prophylactically to prevent atonic $\mathrm{PPH}$ (postpartum hemorrhage). Patient was shifted to ICU post op and blood components were transfused.

3 hours after the cesarean section patient had atonic postpartum haemorrhage. Uterine massage was started, the genital tract was explored, and clots removed. Oxytocin drip (40 units in $500 \mathrm{ml} \mathrm{NS}$ ) was started and 1000 microgram misoprostol was inserted per rectally. The patient continued to have atonic PPH in spite of massage. Since the bleeding did not reduce by medical management alone, balloon tamponade was done. Patient started bleeding from stich line, haemoglobin dropped to 4.2 gram \%, platelet count dropped to 32,000 per microlitre and INR >4.Patient deterioted central line was placed and inotropes were started. A total of 10 units FFP, 7 units PRP, 3 units whole blood and 4 units PCV was transfused. Oxytocin was continued 24 hours postdelivery. Inotropes were tapered post op day 2. The balloon was deflated and removed after further transfusion of FFP and platelets at about 32 hours postdelivery. Abdominal drain was removed on post op day 3. Bilirubin levels gradually came down to near normal by a day 7 .Patient was discharged on post op day 8 after suture removal and advised follow up after 1 week.

\section{DISCUSSION}

To date, there is considerable variation in the definition and terminology of HELLP syndrome. ${ }^{5}$ The diagnostic criteria used is not only variable but inconsistent. ${ }^{6}$ Hemolysis, defined as the presence of microangiopathic hemolytic anemia is the hallmark of HELLP syndrome. ${ }^{7}$ Our case report attempts to illustrate the diagnostic dilemma that a clinician faces in diagnosing an atypical presentation of HELLP syndrome. As illustrated by this case, HELLP syndrome can occur in the setting of a normotensive patient without proteinuria, but with other symptoms present (right upper quadrant pain, epigastric 
pain, shortness of breath, and retrosternal chest pain). HELLP syndrome is not always evident in cases wherein the expected hemolysis, thrombocytopenia, or liver enzyme elevation occurs singularly. ${ }^{8}$ With symptoms like jaundice in absence of hypertension as in our case final diagnosis decision is complicated with other possibilities like acute fatty liver of pregnancy. Management of jaundice during pregnancy especially in third trimester remains a dilemma for the obstetrician because of its varied aetiology, unpredictable prognosis and guarded perinatal outcome. ${ }^{9}$ Authors describe a case of HELLP syndrome with an atypical presentation, authors therefore recommend a rational stepwise approach toward the diagnosis of HELLP syndrome and its atypical presentation. In a patient presenting with any unexplainable laboratory abnormality of either hemolysis or elevated liver enzymes or low platelets, the index of suspicion for HELLP syndrome should remain high in the presence of other symptoms, in this case, epigastric pain. ${ }^{10}$ Clinicians should consider the diagnosis of preeclampsia and HELLP syndrome even in absence of hypertension and protienuria in women presenting with clinical or laboratory abnormalities consistent with this disease.

Funding: No funding sources Conflict of interest: None declared

Ethical approval: Not required

\section{REFERENCES}

1. Stone JH. HELLP syndrome: hemolysis, elevated liver enzymes, and low platelets. Jama. 1998;280(6):559-62.

2. Sibai BM, Taslimi MM, El-Nazer A, Amon E, Mabie BC, Ryan GM. Maternal-perinatal outcome associated with the syndrome of hemolysis, elevated liver enzymes, and low platelets in severe preeclampsia-eclampsia. Am J Obstet Gynecol. 1986;155(3):501-7.
3. Haram K, Svendsen E, Abildgaard U. The HELLP syndrome: clinical issues and management. A Review. BMC Pregn Childbirth. 2009;9(1):8.

4. Rahman H, Pradhan D. Rising trends and changed indications of caesarean sections in Sikkim, India: cause for concern, International Journal of Reproduction, Contraception, Obstetrics and Gynecology. Int J Reprod Contracept Obstet Gynecol. 2016;5(6):1851-6.

5. Martin Jr JN, Rinehart BK, May WL, Magann EF, Terrone DA, Blake PG. The spectrum of severe preeclampsia: comparative analysis by HELLP (hemolysis, elevated liver enzyme levels, and low platelet count) syndrome classification. Am J Obstet Gynecol. 1999;180(6):1373-84.

6. Sibai BM. Diagnosis, controversies, and management of the syndrome of hemolysis, elevated liver enzymes, and low platelet count. Obstet Gynecol. 2004;103(5):981-91.

7. Weinstein L. Syndrome of hemolysis, elevated liver enzymes, and low platelet count: a severe consequence of hypertension in pregnancy. Am J Obstet Gynecol. 1982;142(2):159-67.

8. Stella CL, Malik KM, Sibai BM. HELLP syndrome: an atypical presentation. Am J Obstet Gynecol. 2008;198(5):e6-8.

9. Castro MA, Fassett MJ, Reynolds TB, Shaw KJ, Goodwin TM. Reversible peripartum liver failure: a new perspective on the diagnosis, treatment, and cause of acute fatty liver of pregnancy, based on 28 consecutive cases. Am J Obstet Gynecol. 1999; 181(2):389-95.

10. Stella CL, Sibai BM. Preeclampsia: diagnosis and management of the atypical presentation. J MaternalFetal Neonatal Med. 2006;19(7):381-6.

Cite this article as: Pradhan S, Bhattacharjee S. HELLP syndrome, a difficult diagnosis: a case report. Int J Reprod Contracept Obstet Gynecol 2019;8:1686-8. 